\title{
Multimodalitet som didaktisk kategori
}

Af Thomas Illum Hansen

Korrekt citering af denne artikel efter APA-systemet (American Psychological Association System, 6th Edition): Hansen, T. I. (2018). New Multimodal Designs for Foreign Language Learning. Learning Tech - Tidsskrift for læremidler, didaktik og teknologi, (5), 60-85. DOI: 10.7146/lt.v4i5.111565 


\section{Abstract}

Udgangspunktet for denne artikel er en kritisk-konstruktiv analyse af en række kernebegreber inden for multimodalitetsteori. Hvordan skal et sammensat begreb som multimodalitet egentlig forstås? Og hvordan kan et sprog om multimodalitet udvikles og anvendes inden for en didaktisk teoridannelse? Det kritiske afsæt danner grundlag for en videreudvikling af den socialsemiotiske teori om multimodalitet i en fænomenologisk retning. Artiklen er derfor bygget op om et dobbelt perspektiv på multimodalitet. Hensigten er en gensidig befrugtning af to traditioner, den socialsemiotiske og den fænomenologiske, med henblik på at udvikle et mere konkret fagsprog om multimodalitet, der kan anvendes til didaktisk analyse. Den kritiske del sætter særligt fokus på modus, modalitet og multimodalitet som kernebegreber i en grundlagsdiskussion. Den konstruktive del giver i forlængelse heraf et bud på, hvordan multimodale tegn kan forstås og analyseres med basis i en fænomenologisk teori om krop, tegn og erkendelse. Det didaktiske perspektiv bliver demonstreret med en eksempelanalyse af en multimodal model i et digitalt læremiddel.

The starting point of this article is a critical-constructive analysis of a series of core concepts in theory of multimodality. How is a complex concept such as multimodality really to be understood? And how can a terminology of multimodality be developed and applied in the field of didactic theory? The critical starting point is the foundation for a further development of the social-semiotic theory of multimodality in a phenomenological direction.

Therefore, the article is constructed around a double perspective on multimodality. The purpose is a reciprocal fertilization of two traditions, the social semiotic and the phenomenological, with a view to developing a more concrete terminology of multimodality, which can be applied to didactical analysis. The critical part focuses on mode, modality, and multimodality as core concepts in a discussion of foundation. In continuation hereof, the constructive part will offer a proposal for how multimodal signs can be understood and analyzed on the basis of a phenomenological theory of body, sign, and cognition. The didactical perspective will be demonstrated with an example of an analysis of a multimodal model in a digital learning resource. 


\section{Multimodalitet som didaktisk kategori}

\section{Bidrag til en fænomenologisk didaktik med særligt fokus på multimodalitet}

\section{Indledning}

Umiddelbart lyder "multimodalitet" som et temmelig teknisk fagudtryk, men det er alligevel blevet et pædagogisk buzzword i den danske uddannelsesdiskurs. Skæver man til de omkringliggende lande, kan man iagttage samme tendens. På alle niveauer i uddannelsessystemet taler man om multimodalitet, men taler man om det samme fænomen? Senest er begrebet blevet skrevet ind i den danske læreplan for dansk i grundskolen: Forenklede Folles Mål for faget dansk (2014), men uden at begrebet bliver defineret i den tilhørende vejledning. Leder man efter en definition i lærebogstekster og forskningslitteratur, bliver begrebet ofte forklaret med eksempler (fx kombination af tekst, billeder og lyd) eller brede kulturteoretiske bestemmelser. Det hænger sammen med en anden dobbelthed, nemlig at multimodalitet både bruges som et betegnende begreb om sammensatte tekster og som betegnelse for en tilgang, der anlægger et bredt blik på betydningsdannelse som et kulturelt og historisk fænomen, der involverer en mangfoldighed af semiotiske ressourcer.

Denne dobbelthed bliver let til en vaghed og dermed til et problem. Både for forskning i multimodalitet og for den didaktiske brug af begrebet. Hensigten med denne artikel er derfor i et dobbeltgreb dels at kaste et kritisk blik på multimodalitetsteori, dels at komme med bud på en videreudvikling af multimodalitet som didaktik kategori. Den kritiske del sætter fokus på modus, modalitet og multimodalitet som flydende betegnere inden for den socialsemiotiske diskurs. Dette valg træffes på bekostning af en bredere introduktion til den socialsemiotiske tilgang, der således forudsættes som kontekst for det kritiske afsæt. Den konstruktive del giver et bud på, hvordan en fænomenologisk semiotik kan bidrage til en didaktisk teori om multimodalitet.

Interessen for en didaktisk udvikling af multimodalitetsteori skyldes flere forhold. Teori om multimodalitet anvendes 
til analyse af læremidler og undervisningssituationer, men ofte uden en direkte anknytning til didaktisk teori og i forlængelse heraf heller ikke en tydelig kobling til sammenhænge mellem tegn og kommunikation på den ene side og erkendelse og kognitiv progression på den anden. En væsentlig begrundelse for at udbygge den didaktiske fortolkning af multimodalitet er, at vi med en kombination af en socialsemiotisk og en fænomenologisk tilgang kan forbinde en analyse af historisk variable tegn med en mere grundlæggende forståelse af forskellige typer af tegn og måder at repræsentere på, herunder deres betydning for elevernes læring og kvaliteten af den undervisning, der finder sted.

\section{Et kritisk blik på den social-semiotiske begrebsdannelse}

Receptionen af især Gunther Kress' tekster bærer præg af, at han veksler mellem fortætning og forskydning af betydning. Joe Weinberg indkredser denne særlige stil i et review af Multimodality. A Social Semiotic Approach to Contemporary Communication (2009). På den ene side er der en fascination ved stilen:

99

Some of Kress's claims are broad-sweeping, whole arguments boiled down to easily digestible kernels such as "there is no meaning without framing" [...] These statements - each well supported within the text - are wonderful markers along the journey Kress is taking, acting as sign posts to help get through the intense theory in the majority of the text. (Weinberg, 2010) ${ }^{1}$

1 Review downloadet den 15.3.2015 på:

http://kairos.technorhetoric.net/15.1/reviews/weinberg/index.html 
På den anden side er der en vis frustration over, at Kress' stil ikke er for fastholdere:

99

There is some difficulty following Kress and knowing what he is trying to say. It's not that Kress isn't trying to be clear; if anything, the problem is that he is trying too hard to be clear. He takes so much time explaining and delving into all the tangential meanings that the original point ends up lost or, at best, heavily obfuscated by the surrounded text. (Weinberg, 2010)

Fra min egen læsning af Kress’ tekster kan jeg genkende den modsætningsfyldte læseoplevelse. Styrken ved Kress' stil er, at han sammen med Theo van Leeuwen har formået at etablere multimodalitetsteori som en framing og en afsøgning af et nyt genstandsfelt inden for tekstforskning. Jeg opfatter således hans stil som en del af hans metode. Dels indfører han mange nye begreber, dels tvister og elaborerer han kendte begreber i en undersøgende stil, der netop veksler mellem semantiske fortætninger og forskydninger. Et stiltræk der har den yderligere konsekvens, at man ikke uden videre reducerer forståelsen af multimodalitet ud fra hidtidige teorier om sprog, billeder eller andre repræsentationsformer.

Udfordringen ved en sådan fluktuerende stil er imidlertid, at det er vanskeligt at systematisere begreber og teoridannelse med henblik på formidling, didaktisk brug og valide empiriske undersøgelser. Man kan se flere tegn på denne problematik i receptionen af Kress' tekster. Den er således præget af en stor diversitet i brug og forståelse af hans begreber, og disse bliver sjældent gjort til genstand for en mere systematisk grundlagsdiskussion. Til gengæld er mange optaget af at fortolke og formidle Kress' teori og bidrage med nye analyser af multimodale fænomener (fx Løvland, 2009 og Fink Lorentzen, 2014). Det har skabt et frodigt forskningsfelt, hvor man diskuterer afgræsningen af begreberne med en kritisk opmærksomhed, der baner vejen for en grundlagsdiskussion (Jewitt, Bezemer \& O'Halloran, 2016; Andersen, Boeriis, Maagerø \& Tønnessen, 2015).

Et eksempel på en central problematik er udfordringerne med at oversætte begreberne 'semiotic modes', 'modality' og 'multimodality' til de skandinaviske sprog. Således er der en tradition for at oversætte 'modes' til 'modalitet', endda indimellem i 
forbindelse med direkte oversættelser af Kress-citater (Levinsen \& Sørensen, 2014, s. 209). Problemet er, at Kress og van Leeuwen ikke selv bruger begreberne 'mode' og 'modality' synonymt, men skelner mellem dem allerede i Reading Images. The Grammar of Visual of Design (1996):

99

Semiotic modes, similarly, are shaped by both the intrinsic characteristics and potentialities of the medium and by the requirements, histories and values of societies and their cultures. (Kress \& van Leeuwen, 1996, s. 35)

99

The term 'modality' comes from linguistics and refers to the truth value or credibility of (linguistically realized) statements about the world. (Kress \& van Leeuwen, 1996, s. 155)

Kress og van Leeuwen bidrager dog selv til forvirringen ved ikke at give tydelige eksempler på 'semiotic modes', der forbindes eksplicit med en definition. I forlængelse af ovenstående temmelig brede, kulturteoretiske bestemmelse behandles sprog, skriftsprog og 'visual modes', men det er uklart, hvordan det kan være sammenlignelige 'semiotic modes'.

I et helt kapitel om modalitet behandles modalitet som en grammatik for realitetskonstruktion og realitetstilskrivning i relation til såvel sprog som visuel kommunikation (Kress \& van Leeuwen, 1996, s. 154-174). Det kræver en høj grad af abstraktion at sammenligne sproglig modalitet (fx modalverber som 'kan', 'vil' og 'må', der angiver forskellige grader af mulighed og sandsynlighed) med modalitet for visuel kommunikation (fx skalaer for farvemætning, -differentiering og -modulering og deres betydning for graden af 'naturalistisk modalitet'). Sammenligningen er på én gang spændende og problematisk, fordi den vinkler sproglig modalitet skarpt i retning af et realismeparameter, der bryder med et mere klassisk lingvistisk modalitetsbegreb (Bybee, Perkins \& Pagliuca, 1994).

Dette traditionsbrud er ikke et problem i sig selv, men det er derimod det forhold, at det ikke bliver behandlet og begrundet i relation til den lingvistiske tradition som en kreativ nyfortolkning. Kress og van Leeuwen åbner således et nyt perspektiv på 'modalitet', men efterlader samtidig læseren med en række ubesvarede spørgsmål. Skal modalitet forstås som et realismeparameter? Er modalitet en definerende egenskab ved 'semiotic 
modes'? Kress og van Leeuwens tilgang lægger op til, at man tolker 'modalitet' generelt som et begreb om mærkning af meddelelser, der markerer, hvordan man skal forholde sig til meddelelsens indhold, og det åbner for en bredere undersøgelse af 'modalitet' ved 'semiotic modes', der vedrører flere parametre for de grader af fx realitetsstatus, informationsværdi og attraktionsværdi, man tilskriver et indhold.

Denne form for modalitetsanalyse spiller en påfaldende lille rolle i skandinavisk reception af multimodalitetsteori. Faktisk synes forvekslingen af 'modality' og 'semiotic modes' at have sløret opmærksomheden over for modalitet som en væsentlig repræsentationsproblematik, der vedrører andre former for repræsentation end den sproglige.

Denne problematik forstærkes af, at det er vanskeligt at afgrænse, hvad der falder inden for begrebet 'semiotic modes'. Hvor Kress og van Leeuwen allerede i Reading Images. The Grammar of Visual of Design primært behandler sprog og visuel kommunikation som 'modes', dér befinder flere af deres eksempler på 'modes' sig sidenhen på et mere konkret niveau:

99

Music is analysed into this digital code just as much as image is, or graphic word, or other modes. (Kress, 2003, s. 5)

9

There is no room for discussing the modality of other semiotic modes [...] the modality of sound can be approached along the same lines as the modality of visual communication. (van Leeuwen, 2005, s. 175)

99

Image, writing, layout, speech, moving images are examples of different modes. (Kress, 2010, s. 79)

Der skelnes blandt andet ud fra sansemodaliteter (skrift er visuel, tale auditiv) og bevægelse (billeder er statiske, levende billeder dynamiske). Desuden åbner eksempler som 'musik, 'layout' og 'lyd' for helt andre typer af spørgsmål. Repræsenterer musik og layout indhold på en måde, der gør dem sammenlignelige med skrift, tale og billeder? Er lyd ikke et materiale, der fx både kan bruges som medium for talt sprog og for auditive billeder (lydbilleder), hvis henholdsvise symbolske og ikoniske tegnfunktion gør dem til ret forskelligartede former for repræsentation? 
På den baggrund forstår man bedre begrebsforvirringen. Hertil kommer, at begrebet multimodalitet af Kress og van Leeuwen bruges om en kombination af 'semiotic modes', og ikke om en kombination af 'modaliteter', som sammensætningen af 'multi' og 'modalitet' ellers antyder. Flerheden af modaliteter er med andre ord udelukkende en afledt effekt, og selv den forståelse forudsætter, at man accepterer en tvistet og generaliseret brug af begrebet modalitet. Endelig bør det tilføjes, at den brede socialsemiotiske bestemmelse af 'semiotic modes' indebærer, at alle tekster er multimodale:

99

All texts have always been multimodal, that is, are always, have always been constituted through a number of semiotic modes. (Kress, 1996, s. 20)

99

Texts are always multimodal, so the rhetorical and design decisions lead to the making of ensembles of modes; these are themselves assembled as orchestrations of modes, in which purposes and needs of the maker of sign-frames are brought together with affordances in the best possible manner, from the rhetor's and the designer's perspective.

(Kress, 2009, s. 157)

Selv den mest monomodale tekst, man kan forestille sig, vil således ud fra den brede bestemmelse være konstitueret af minimum skriftsprog, grafik og layout, der varetager forskellige tegnfunktioner. Man kan her bemærke, at termen 'multimodalitet' mister sin prædikationskraft og intensionelle betydning (at den udpeger en bestemt type af tekster) i takt med, at den øger sit omfang og ekstensionelle betydning.

Multimodalitet er med andre ord ikke et adskillende træk ved tekster, men snarere et konstituerende træk, hvilket synes at stå i kontrast til den typiske brug af termen i læreplaner og pædagogisk praksis. Dette gælder ikke kun den seneste læreplan for dansk i grundskolen. En amerikansk survey-undersøgelse fra 2006 blandt professionelle, der underviser i multimodal komposition, peger således på, at der er stor diversitet i forståelsen af begrebet, og at $62 \%$ opfatter en multimodal tekst som en tekst, der inkluderer "a range of communicative modes including media such as audio, video, animation, words, images, and others" (Anderson, Atkins, Ball, Millar, Selfe \& Selfe, 2006, s. 69). 


\section{Fænomenologisk semiotik}

Den fremførte kritik kan opsummeres som en række kritiske elementer, vi bør være opmærksomme på i en videreudvikling af multimodalitetsteori. Således er der behov for et skarpere fokus på definerende træk ved begreber, en mere adækvat oversættelse og reception af terminologien i de skandinaviske lande, en mere kritisk grundlagsdiskussion inden for teoridannelsen samt en mere eksplicit forholden sig til de traditioner, man dels trækker på (fx et lingvistisk modalitetsbegreb), dels udgrænser (fx Charles S. Peirces semiotik eller Jerome Bruners repræsentationsteori).

Sidstnævnte udgrænsninger kan undre. Peirce er kendt som grundlægger af semiotikken og med blandt andre John Dewey også af pragmatisk filosofi. Ikke alene foregriber han et bredt tegnbegreb, som omfatter mere end det sproglige tegn, men også en bredere kontekstuel forståelse af tegn. Bruner er i forlængelse heraf ikke mindst kendt for en læringsteori, hvor han med inspiration fra Peirce og Jean Piaget tildeler repræsentationsformer en helt central kognitiv funktion. Sammenligner man de engelske begreber, forekommer 'modes of representation' og 'semiotic modes' beslægtede. En væsentlig forskel er, at Bruner beskæftiger sig med indre repræsentationer og tegnmæssig progression som kognitivt omdrejningspunkt for hans læringsteori. Ifølge Kress hører begrebet 'læring' imidlertid ikke til inden for semiotikken (Kress, 2003, s. 40). Kress tilføjer dog straks, at læring og tegndannelse er to sider af samme sag, bare set fra forskellige perspektiver, et psykologisk og et semiotisk.

Udover denne bemærkning, synes Kress ikke at interessere sig for den mentale inderside af tegndannelse eller for modtagerens fortolkning af tegn, den proces Umberto Eco i forlængelse af Peirce betegner den uendelige semiosis. I Multimodality. A Social Semiotic Approach to Contemporary Communication skal man helt frem til side 72, før Kress nævner, at en tegnproducent må tage hensyn til et publikum. Det understreger, at Kress primært interesserer sig for tegn som noget, der er i verden med en vis materialitet og potentialitet, kaldet 'modal affordans', men han beskæftiger sig mindre med, at en sådan affordans må have et kognitivt korrelat. Multimodalitetsteorien er således ikke forankret i en fænomenologisk semiotik og epistemologi, der forklarer eller undersøger sammenhænge mellem tegns modale affordans på den ene side og tegnbrugernes kognitive og affektive kapacitet på den anden.

I det lys er det interessant at gribe tilbage til epistemologisk 
forankrede tegnteorier inden for pragmatisk og fænomenologisk filosofi. ${ }^{2}$ Ud over Peirce har Edmund Husserl ligeledes et omfattende forfatterskab om tegn og erkendelse. I denne sammenhæng vil jeg begrænse mig til at fremhæve et eksempel på en beslægtet begrebslighed hos de to, der giver et indtryk af, hvad disse traditioner kan bidrage med til mit forsøg på at udvikle en didaktisk teori om multimodalitet. ${ }^{3}$ Således kan Husserls skel mellem henholdsvis perceptive, imaginative og signitive bevidsthedsakter forbindes med Peirces skel mellem indeksikalske, ikoniske og symbolske tegn, det vil sige tegn, der bygger på henholdsvis nærhed og sammenhæng (indeksikalsk tegn: en snegl på vejen er tegn på regn), lighed (ikonisk tegn: en animation) eller symbolsk konvention (symbolsk funktion: et sprogligt begreb som fx "ko").

Indeksikalske tegn bygger på den form for sanselig anskuelse, som Husserl betegner som "perceptive akter" (perception = sanselig anskuelse). Fx er et glas vin på et bord givet direkte i anskuelsen, når man perciperer det. Samtidig fungerer gentagelsen af bestemte oplevelser i bestemte situationer som indeksikalske tegn på sammenhænge, der kan gøres til genstand for bearbejdning og erfaringsdannelse. Et glas rødvin kan blandt andet være en velkomstgestus.

De ikoniske tegn bygger på den form for billedlig anskuelse, som Husserl betegner som "imaginative akter" (imagination = billedskabende kraft). Den imaginative repræsentation kan både være ydre og indre - afhængigt af om man benytter et ydre medium eller ens egen krop og bevidsthed som medium. Fx et fotogra$f i$ af et glas vin på et bord (ydre billedlig) eller et erindringsbillede af et glas vin på et bord (indre forestilling).

De symbolske tegn bygger på den form for symbolske og ikke-anskuelige bevidsthedsakter, som Husserl betegner "signitive akter" (sign = tegn). Man bør bemærke, at Husserl i denne sammenhæng bruger tegnbegrebet snævert. Ifølge Peirces bredere tegnbegreb må alle tre typer af bevidsthedsakter være 'signitive'. Husserl anvender således begrebet 'signitiv' om en symbolbaseret akttype, der er den mindst umiddelbare, fordi genstande og rela-

2 Denne fremstilling af Peirce og Husserl er en sammenfatning af en mere udførlig behandling i Hansen, 2012, s. 145-162, der igen er en komprimering af de to meget omfattende epistemologier i Husserl (1900-01/1995), Husserl (2005) og Peirce (1998).

3 Udviklingen af didaktisk multimodalitetsteori er tidligere behandlet i bl.a. Hansen (2010), Hansen (2011), Hansen (2012). 
tioner er repræsenteret ikke-anskueligt i kraft af tegn, der henviser med basis i symbolske regler og konventioner. Udtrykket "der står et glas vin på et bord" repræsenterer ikke med basis i nærhed eller lighed, men i kraft af bl.a. (der er flere systemer end det grammatiske på spil i sætningen) en konventionel og regelstyret brug af substantiver, verbum og præpositionsforbindelse.

Jerome Bruner var den første, der omsatte Peirces tre tegnfunktioner i en læringsteori med tre repræsentationsformer: den udøvende ('enactive'), den ikoniske og den symbolske (Bruner, 1966, s. 6). Bruner så - ligesom i øvrigt Jean Piaget og Bärbel Inhelder (1966/2002) - en klar progression fra det konkret, kropslige mod det abstrakt, symbolske og understregede denne progression ved at tolke den indeksikalske tegnfunktion som kropslig udøvelse i undervisningen.

Bruners forholdsvis enkle tolkning af Peirce rummer en risiko for at forsimple den bagvedliggende teori om tegn og erkendelse. Derfor skelner jeg dels mellem tegnfunktioner og ydre repræsentationsformer, dels mellem indre og ydre repræsentationer (tegn kan, som nævnt ovenfor, godt være indre). Hensigten er at udvikle en mere finkornet teori om multimodalitet, der bedre kan bruges didaktisk til at forklare relevante sammenhænge mellem semiotik, læring og undervisning. Således inddeler jeg de tre tegnfunktioner, så der i alt skelnes mellem seks repræsentationsformer. Begrundelser herfor bygger primært på Peirce og Husserls fænomenologiske analyser, men de udbygges med didaktiske argumenter.

Det første og mest basale skel vedrører indeksikalske tegn, der kan inddeles i kropslige og genstandsmæssige. Der er væsentlig forskel på at bruge kroppen som udtryk for et indhold og på at forstå genstande i omverdenen som udtryk for noget. En krop er jo andet og mere end en genstand. Den kan både opleves indefra og iagttages udefra, og så kan den bruges til at pege og gestikulere med. Set ud fra et lærerperspektiv er den mest grundlæggende gestus at pege på, vise frem og, med Alexander von Oettingens udtryk, at vise, hvad der ligger under. Omvendt er elevens urgestus at se og blive set. Se, hvad læreren viser frem, og at vise og demonstrere, at man har forstået. Den sociale og faglige interaktion i undervisningen er anledning til udveksling af blikke og perspektiver samt kropsligt baseret overførsel af forståelse. Desuden er kroppen udgangspunktet for den gradvise abstraktion fra krop til symbol. Til sammenligning er genstande og fænomener i omverdenen forbundet af kausale relationer, der får dem til at henvise 
til hinanden som spor eller symptom, fx mos i græsplænen som tegn på bestemte forhold vedrørende lys og jordbund.

Man bør i øvrigt bemærke, at både kroppe og genstande bruges til billedlig repræsentation, fx hvis man bevæger håndfladerne frem og tilbage over hinanden for at repræsentere kontinentalfladernes forskydning (en typisk måde at bruge en kropslig, billedlig repræsentationsform på inden for pladetektonik). I forbindelse med en analyse må man derfor vurdere, hvilken tegnfunktion der er den primære.

På tilsvarende vis inddeles de to andre tegnfunktioner med henblik på didaktisk brug og med argumenter, der samtidig kan føres tilbage til Peirces skel mellem forskellige typer af ikoniske tegn (billede og diagram) og symbolske tegnsystemer (naturlige sprog og symbolske notationssystemer).

Figur 1. Udkast til en model for multimodal progression.
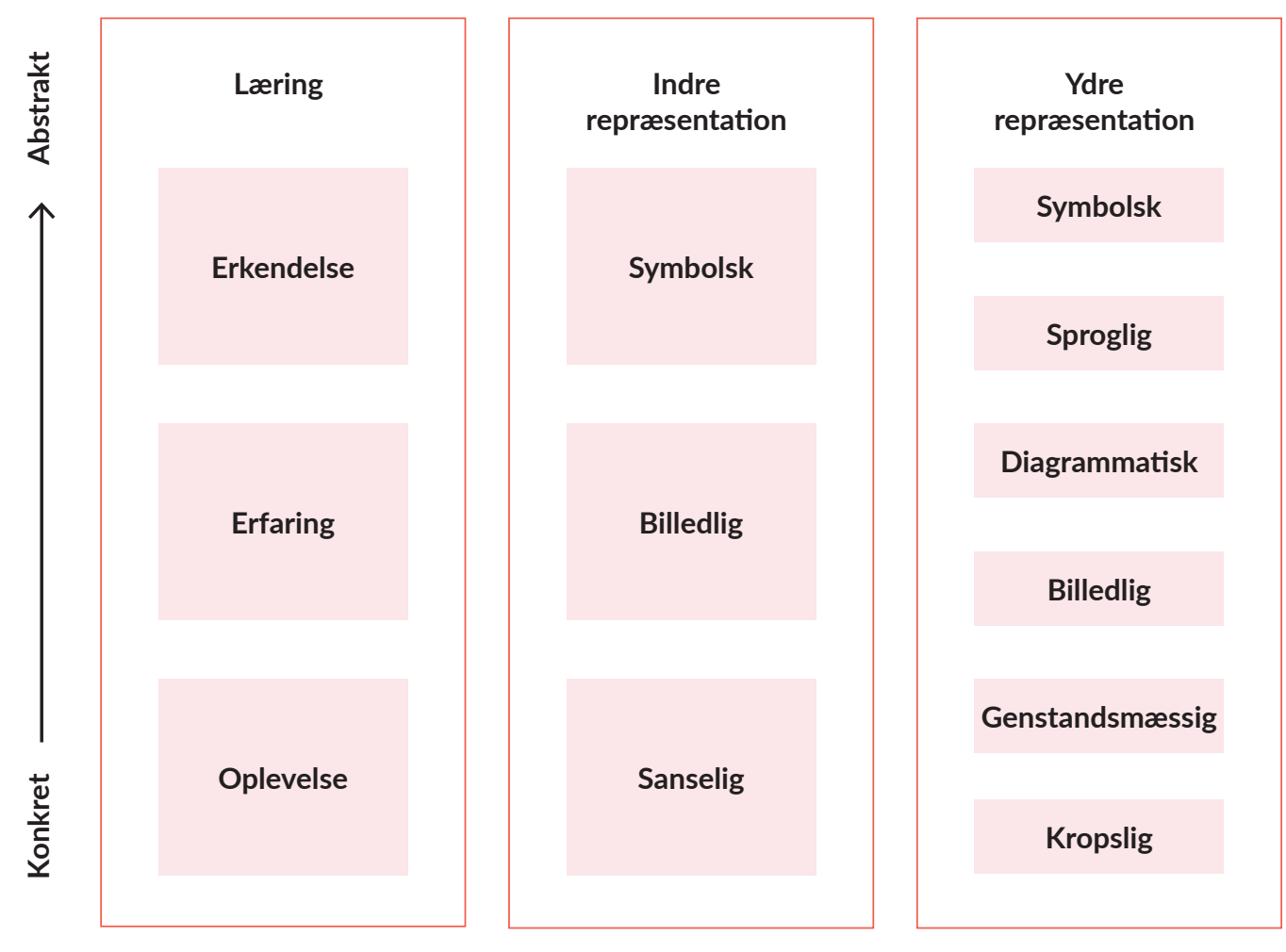
Progressionen nedefra-og-op gengiver grad af abstraktion og konvention. I traditionen efter Bruner og Piaget har der været en tendens til at tolke de tre tegnfunktioner håndfast som faser i en kognitiv udvikling. Derfor er det vigtigt at erindre, at både Peirce og Husserl analyserer tegntyper og bevidsthedsakter som dybt integrerede funktioner, der nok kan adskilles analytisk, men som er nært forbundne i den praktiske brug af tegn til kognition og kommunikation. Det betyder, at multimodal repræsentation ikke blot er et spørgsmål om at sætte adskilte repræsentationsformer sammen til et udtryk, men snarere skal forstås som et grundlæggende træk ved den menneskelige erfaringsdannelse, der gør, at vi har en kognitivt begrundet tendens til at bruge flere repræsentationsformer i sammenhæng, når vi skal udtrykke os.

Denne pointe kan underbygges med nyere empiriske studier af børns kognitive udvikling, der peger på, at der allerede i en tidlig alder er tale om en ret sofistikeret begrebsdannelse, som indebærer en vis samtidighed i de centrale kognitive funktioner. Jean Mandler har således opsummeret en lang række empiriske studier under den polemiske overskrift "Going Beyond Piaget":

9

Right from the beginning, or at least from a few months of age, babies function in ways that merge continuously into those of older children and adults. They form concepts, they have notions of different kinds, they generalize from their experiences on the basis of the concepts they have already formed, and they are reminded of absent objects and events by this or that cue and recall them. These capacities mean that from the start babies are forming a declarative knowledge system, one that they use to give meaning to what they see and that a year later will help them acquire language to talk about what they see. This is a rather different baby from the one described by Piaget. (Mandler, 2004, s. 11).

Mandlers kritik af Piaget skal ikke forfølges her, men det kan kort bemærkes, at den hænger sammen med et generelt opgør med den tidligere udviklingspsykologis faseinddelinger og tendensen til at overdrive sprogets betydning for børns begrebsdannelse. Retfærdigvis skal det tilføjes, at Mandler i øvrigt viderefører en del af Piagets tanker, men det interessante i denne sammenhæng er, at de empiriske studier peger på de kognitive funktio- 
ners samtidighed. Den form for erkendelse, Mandler beskriver, kræver et samspil mellem tegnfunktioner fra en tidlig alder. Den symbolske tegnfunktion indbefatter deklarative vidensformer, der altså allerede er ved at blive dannet i en tidlig alder.

Omvendt betyder Peirce og Husserls analyser af integrerede funktioner, at progression ikke bør forstås på den måde, at man kan lægge de indeksikalske og ikoniske tegn bag sig, når man er blevet så kognitivt udviklet, at man i vid udstrækning kommunikerer i kraft af symbolske tegn. Der er en konstitutiv sammenhæng mellem tegnfunktioner, der gælder alle aldre. Således er der en grad af symbolsk konvention forbundet med de fortolkningsvaner, der udvikles i relation til indeksikalske og ikoniske tegn. Et eksempel er landkort, hvor den ikoniske tegnfunktion er central (et kort skal afbilde et landskab i flere henseender, så man kan bruge det til at skabe overblik og orientere sig), men den symbolske tegnfunktion er også tydelig, hvorfor man taler om at kunne læse kort. Den indeksikalske tegnfunktion spiller ligeledes en rolle, da man skal have en kropslig fornemmelse for, hvad det vil sige at bevæge sig igennem et landskab.

Integrationen af tegnfunktioner viser sig også ved, at selv kropslige pegefunktioner og naturalistiske fotografier er stærkt konventionaliserede symbolske former. Fx anvendes pegefunktionen med forskellige betydninger og høflighedsformer i forbindelse med optælling af dyr, håndsoprækning, udpegning af gerningsmænd, pegen fingre ad andre og nysgerrig udpegning af en kendt person.

\section{Skitse til en fænomenologisk forankret multimodalitetsteori}

I forlængelse af den kritiske ansats vil jeg pege på, hvor de to traditioner, den fænomenologiske og den socialsemiotiske, kan mødes og bidrage til videreudvikling af en didaktisk teori om multimodalitet. På den ene side kan den fænomenologiske semiotik bruges til at forklare tegnets kognitive funktioner ud fra en kropsligt forankret epistemologi og en forholdsvis afgrænset systematik med seks repræsentationsformer, mens den socialsemiotiske tilgang åbner for en bredere analyse af tegnets kulturelle kontekst. 
Figur 2. Udkast til en fænomenologisk forankret teori om repræsentationsformer.

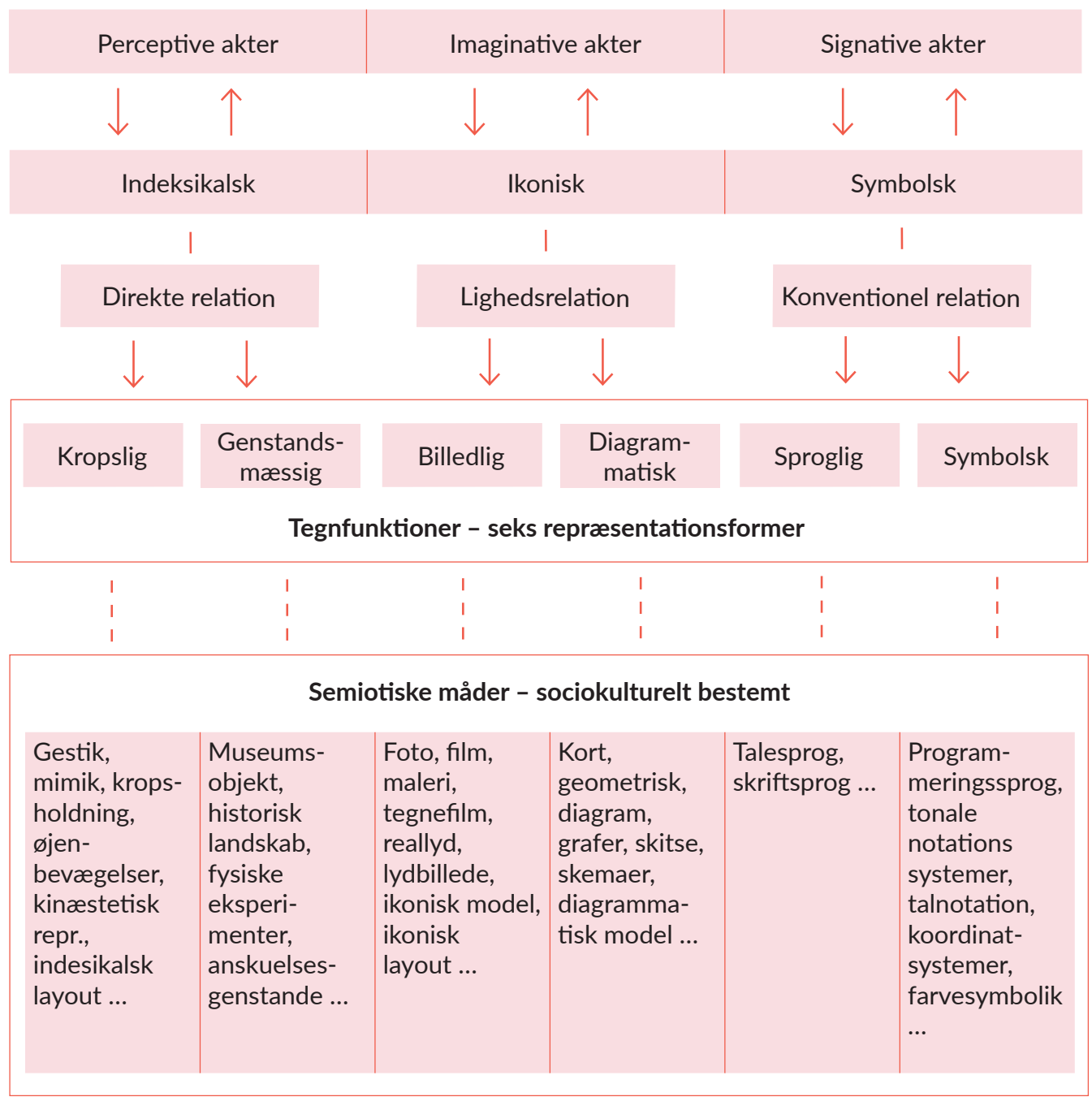


De to øverste bjælker tydeliggør typologiens fænomenologiske forankring. Den luft, der er imellem de to bjælker og selve skemaet, illustrerer, at man ikke kan sætte lighedstegn mellem bevidsthed, tegnfunktion og ydre repræsentationsform. Der ligger en kombination af tegntyper og akter til grund for de enkelte repræsentationsformer, så sammenstillingen skal forstås som en fremhævelse af de dominerende akter og tegnfunktioner.

Underinddelingen af repræsentationsformer i mere sansespecifikke semiotiske modi er åben og undersøgende, fordi den ikke alene er bestemt ud fra en fænomenologisk semiotik og epistemologi, men i lige så høj grad ud fra kulturelt variable betingelser for tegndannelse. Der er derfor ikke tale om en stringent systematik, men derimod om en opregning af relevante skel på et niveau, der er beslægtet med Gunther Kress og Theo van Leeuwens semiotiske modi, fx skrift, tale og statisk billede. Min pointe med denne skematiske opstilling er, at repræsentationsformernes systematik foroven og deres prototypiske kognitive funktioner kan forklares ud fra menneskets kognitive kapacitet. Forneden i skemaet befinder de konkrete modi og eksempler sig, og de har ikke samme systematik, fordi deres eksistens og udbredelse er kulturelt bestemt og således afhænger af aktuelt tilgængelige semiotiske ressourcer. Relevansen af de anførte skel er således en historisk og kulturel variabel. Fx er billedlig repræsentation af levende lyd og billede afhængig af den teknologiske udvikling, der har gjort det muligt at anvende lys på skærm som et plastisk medie. Den billedelige repræsentation bliver i øvrigt ofte reduceret til visuel billedlighed, men med den digitale teknologi er det efterhånden muligt at skabe interaktive hologrammer, der kombinerer lyd, lys, bevægelse og forsøgsvis også dufte i en udvidet genskabelse af virkeligheden ('augmented reality'). Når en sådan teknologi bliver mere udbredt, kan det blive relevant at skelne mellem flere dimensioner og sansemodaliteter i relation til billedlig repræsentation, fx visuel, auditiv, taktil, kinæstetisk og olfaktorisk.

Med afsæt i den fænomenologiske forankring af multimodalitetsteori kan vi stille en række kritiske spørgsmål til opfattelsen af multimodalitet, der åbner for nye perspektiver på forholdet mellem repræsentationsformer. Det gælder både forvekslinger, fx af det multimediale og det multimodale, og afklaring af det kognitive samspil mellem repræsentationsformer.

Er alle tekster per definition multimodale? Layout og grafisk opsætning understøtter typisk læserens orientering, 
men bidrager layout til tekstens repræsentation på en måde, der kvalificerer den til at være en multimodal komposition? Og hvad med multimedieproduktioner, er de nødvendigvis multimodale? Filmsekvenser med levende billeder og synkron reallyd er multimediale (kombinerer lyd og lys på skærm), men er de multimodale, hvis der er tale om en synkron billedlig repræsentation?

Spørgsmålene er til dels retorisk formulerede, men de er samtidig ment reelt, da de ikke kun vedrører, hvordan vi definerer multimodalitet, men også hvordan vi opfatter og fortolker multimodalitet i mødet med tekster. Tag fx teksters layout, der typisk er med til at styre læserens opmærksomhed og guide via placering, størrelse, retning og orienteringspunkter. Et layout, der styrer læserens opmærksomhed og navigation, tolker jeg ud fra den indeksikalske tegnfunktion som en form for kropslig repræsentation. Jeg mener således, at der er tale om mere end sproglige metaforer, når man taler om 'guide', 'læsesti' og 'navigation'. Der er mere præcist tale om en kognitiv grundmetafor, hvor den pegende, gestikulerende og oplevende krop danner grundlag for en forståelse af det bevægelsesmønster, der er indbygget som en intenderet del af et layout. Det betyder mere generelt, at den dynamiske del af et design kan opfattes som en virtuel kropslighed, der forstås i kraft af den perciperende krops fornemmelse for eget bevægelsespotentiale (også kaldet 'proprioception'). Det er blevet tydeligt med digitale designs for interaktion, men som det gerne skulle fremgå af mit eksempel, er den virtuelle krop en både mere generel og kognitivt set mere basal størrelse, der er blevet ekspliciteret med digitaliseringen af interaktive designs.

Det specielle for den kognitive kropsmetafor er, at den kropslige repræsentation ofte er mulig i kraft af andre repræsentationsformer, fx diagrammatisk repræsentation (stiliserede pile, punkter, streger og flader) og sproglig repræsentation (udtryk som 'jeg,' 'du', 'her', 'der', 'nu' og 'da' analyseres som 'skiftere' og som 'deiksis' inden for lingvistikken, fordi de skaber et pegefelt i sproget). I det hele taget er der ofte et nært samspil mellem repræsentationsformer, hvilket netop kan forklares med, at tegnfunktionerne er kognitivt forbundet, så de ikke findes i ren form. I den forstand er alle tekster multimodale. Derfor vil jeg foreslå en graduering af kategorien multimodalitet, så den stadig kan bruges meningsfuldt som prædikat.

Det vil jeg gøre ud fra et overordnet skel mellem to typer af repræsentation, der især er tydeligt i didaktiske læremidler. På den ene side er der en repræsentation af et fagligt indhold, der er 
genstand for brugerens opmærksomhed (en funktion, der inden for socialsemiotik betegnes ideationel repræsentationsfunktion). Det er typisk billeder, diagrammer, skrift, tale og symbolsk notation, der fremstiller og begrebsliggør et fagligt indhold (ikonisk og symbolsk tegnfunktion). På den anden side er der som beskrevet ovenfor en repræsentation, der er med til at indramme og styre opmærksomheden, men som ikke selv er i fokus (inden for socialsemiotik taler man her ofte om tekstuel funktion). Det er typisk grafik, farver, opsætning og lydspor, der angiver handlemuligheder, opmærksomhedsretninger og stemninger (indeksikalsk tegnfunktion).

Den første type af repræsentation har især betydning for det didaktiske design og muligheden for at interagere med et fagligt indhold i dybden.

Den anden type har derimod primært betydning for læremidlets brugergrænseflade og muligheden for at interagere på overfladen, dvs. om læremidlet er nemt, hurtigt og intuitivt at bruge, og om dets design har æstetiske kvaliteter.

Min påstand er, at det er repræsentation af indhold, der er bestemmende for, om man registrerer teksters multimodalitet. Prototypen på en multimodal erfaret tekst er ifølge denne tanke en tekst, hvor indholdet er repræsenteret via flere repræsentationsformer, fx sproglig, billedlig, diagrammatisk og symbolsk. Er indholdet repræsenteret via flere modi inden for én repræsentationsform, kan der opstå tvivl. En digital tekst med syntetisk oplæsning af en læsbar tekst er multimedial, men er den multimodal? Dette spørgsmål kan let føre til en længere diskussion om, hvorvidt man oplever en modal forskel, og om denne forskel har betydning for en forståelse af det fremstillede indhold. Endelig er der fx bøger med skrift og et diskret layout, der understøtter læseformål. Sidstnævnte vil jeg beskrive som tekster, hvis multimodale komposition skaber en gestalt, der erfares som monomodal, fordi deres grafik og layout ikke påkalder sig opmærksomhed og bidrager tydeligt til en direkte repræsentation af tekstens indhold, men kun indirekte ved at understøtte læsningen.

Det samme gælder de dele af et layout i didaktiske læremidler, der bygger på symbolsk repræsentation, fx når der er farvekoder, der understøtter den faglige læsning, så fx formidlings-, opgave-, evaluerings- og analysetekster har hver deres farve. Farvekoderne er afgørende for den genreforståelse, man møder tekster med, og herigennem det indhold, der repræsenteres, men 
farvekodens funktion er stadig indirekte, fordi der er tale om en rammesætning af de tekster, der repræsenterer det faglige indhold.

\section{Didaktisk analyse af multimodal model}

Den fænomenologiske semiotik gør det muligt at skærpe den didaktiske analyse af multimodalitet ved at forbinde udtryksmønstre med potentielle erkendelsesmønstre. Det vil jeg forsøge at demonstrere med en analyse af et eksempel på didaktisk brug af multimodalitet i en interaktiv model til undervisning i genrer.

Figur 3. Multimodal, interaktiv model til repræsentation af genrer i www.dansk.gyldendal.dk.

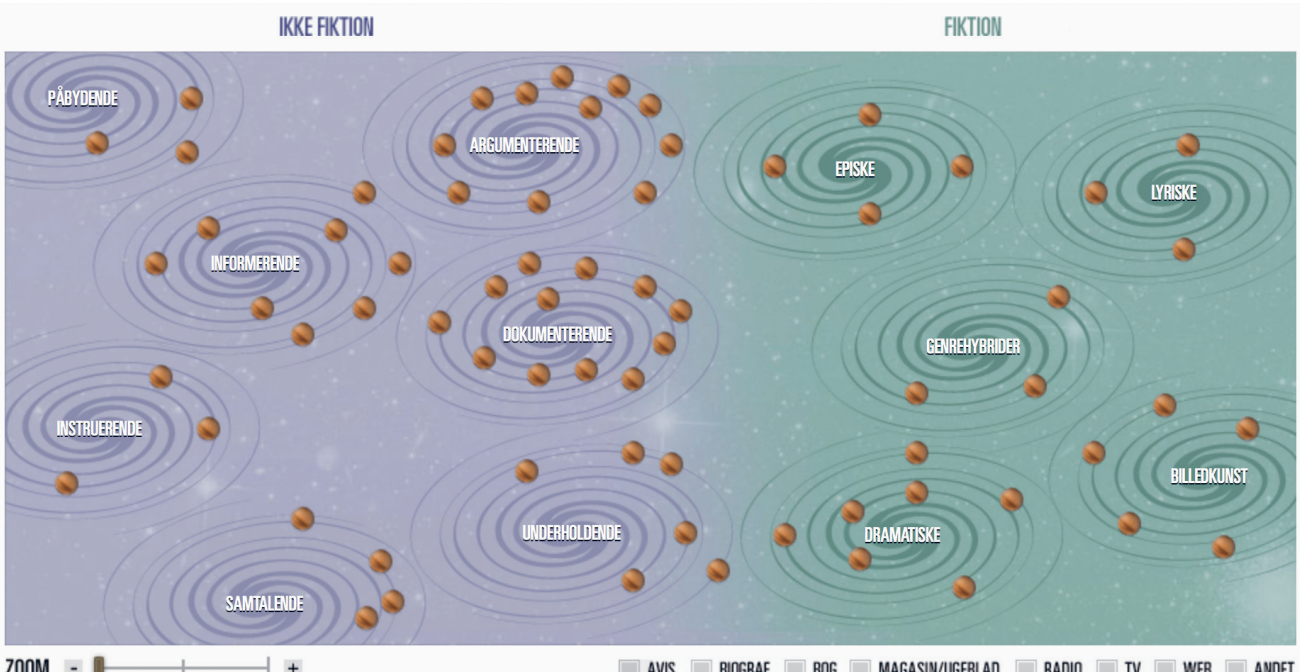


Den interaktive model i Figur 3 er et eksempel på, at der anvendes flere repræsentationsformer i sammenhæng for at repræsentere et vanskeligt fagligt indhold fra flere perspektiver. Den billedlige repræsentation (aktuelt et univers med flere solsystemer) bruges som grundlag for en diagrammatisk repræsentation (aktuelt en genretypologi med faglige kategorier og relationer). Den sproglige repræsentation bruges til at introducere faglige skel og begreber i en beskrivende fremstillingsform. Den symbolske repræsentation er derimod ikke fremtrædende. De symbolske tegn '+','-' og 'x' anvendes til at markere zoom-effekt og lukkemekanisme, men fx farveforskellen mellem de fiktive og ikke-fiktive genrer er ikke konventionel og derfor snarere et eksempel på en indeksikalsk pegefunktion.

De forskellige repræsentationsformer har tydeligvis forskellige muligheder og begrænsninger, der i tråd med den socialsemiotiske tradition kan beskrives med den amerikanske perceptionspsykolog James J. Gibson begreb "affordance", da det vedrører, hvad repræsentationsformerne kan give (eng. afford) af handle- og betydningsmuligheder (Kress, 2003, s. 50; van Leeuwen, 2005, s. 4; Løvland, 2009, s. 124).

Den sproglige repræsentation er eksempelvis velegnet til at fremstille tidslige forhold og rækkefølge, forklare sammenhænge og beskrive egenskaber. Billeder kan også anvendes sekventielt som tidslig rækkefølge, men udmærker sig især ved at kunne gengive rumlige forhold og sansekvaliteter. Anvendes den billedlige repræsentation mere abstrakt som diagram, fungerer den godt som en diagrammatisk repræsentation af relationer og struktur. En læsning af skærmbilledet i Figur 3 kan bruges som eksempel på, at man skifter mellem scanning og orientering i et rumligt univers og sekventiel læsning og fordybelse i tidsligt strukturerede tekster, når man forsøger at forstå modellen.

Modellens samlede 'modale affordans' afhænger af den univers-metafor, der ligger til grund for den konkrete kombination af repræsentationsformer. Derfor er metaforen et godt udgangspunkt for en kritisk læsning. Hvad vil det sige, at genrer er beslægtede som planeter i et solsystem? Hvordan skal det forstås, at solen i de enkelte systemer er skiftet ud med fremstillingsformer ( $\mathrm{fx}$ instruerende eller informerende) og litterære storgenrer ( $\mathrm{fx}$ lyriske og episke)? Er det storgenrer, der skaber et solsystem med flere genrer ved deres tyngdekraft i overført forstand? Hvordan er forholdet mellem forskellige systemer? 
Modellen er kompleks. Højre/venstre-relation repræsenterer fiktive/ikke-fiktive genrer. Cursoren aktiverer både en pop-op tekst og en farvemarkering ud for de kanaler eller udbredelsesmedier forneden til højre, som genren typisk distribueres via: avis, biograf, bog, magasin/ugeblad, radio, tv, web og andet. Zoomskyderen gør det muligt at komme tættere på de enkelte systemer, hvorved der fx dukker undergenrer op. En kritisk læsning indbefatter derfor en diskussion af det interaktionsdesign, der er skabt med afsæt i metaforen.

Den overordnede inddeling ud fra fremstillingsformer og storgenrer gør, at modellen umiddelbart fremstår abstrakt og vanskelig. Der er pakket mange informationer i relationerne mellem planeter og systemer. De ikke-fiktive genrer til venstre er defineret ud fra deres funktionelle formål, mens de fiktive genrer til højre er defineret ud deres typiske æstetiske form. Kan man sammenligne solsystemer, der er skabt på så forskellig vis?

\section{Multimodal affordans}

Eksemplet på en interaktiv brug af multimodalitet demonstrerer, at modal affordans ikke alene hænger sammen med den affordans, der knytter sig til de enkelte repræsentationsformer eller semiotiske modi, men i lige så høj grad til den affordans, der ligger i den aktuelle kombination. Der er således mere præcist tale om en 'multimodal affordans'.

Genreuniverset repræsenterer en form for multimodalitet, hvor den sproglige repræsentation anvendes til at beskrive eller forklare i relation til en diagrammatisk repræsentation. Det er en udbredt form for multimodalitet i forbindelse med modeller, men den er kun én blandt flere. Med afsæt i den kropsligt forankrede epistemologi kan de forskellige former for modal affordans og multimodal affordans præciseres.

Inden for den socialsemiotiske tradition analyseres kombinationen af 'semiotiske modi' ud fra Theo van Leeuwens videreudvikling af Roland Barthes' typologi for kobling af tekst og billede (van Leeuwen, 2005, s. 230). En mere fyldestgørende diskussion af denne typologi ligger uden for rammerne af denne artikel, men jeg vil ganske kort fremdrage principperne i min fænomenologiske fortolkning af de multimodale koblinger. Den epistemologiske forankring og kognitive progression fra konkret til abstrakt repræsentation medfører, at jeg tillægger relationer- 
ne mellem repræsentationsformerne en større og mere selvstændig betydning.

Den socialsemiotiske tolkning af Barthes' typologi sætter fokus på informationskoblinger mellem ord og billede. Det har givet gode og operationelle skel mellem fx specificering (ord identificerer den billedlige repræsentation), forklaring (ord forklarer den billedlige repræsentation) og komplementering (ord og billede supplerer hinanden, som det er kendt fra tegneserier). Disse typer tolker jeg med inspiration fra kognitiv metaforteori (Lakoff \& Turner, 1989; Fauconnier, 1998) som et kontinuum, der strækker sig fra simpel kobling (identifikation) til kompleks konceptuel integration (nye betydninger opstår, som det er kendt fra den kreative kobling af tekst og billeder i en 'graphic novel').

Beslægtet med Barthes og van Leeuwen skelner jeg mellem seks former for multimodalitet: tre former for multimodal udfoldelse, hvor kombinationen af repræsentationsformer bidrager til en forholdsvis entydig forståelse (fx i form af et billede, der anskueliggør handlingen i teksten), og tre former for multimodal udvidelse, der skaber et mere eller mindre flertydigt fortolkningsrum (fx et billede, der ikke mimer handlingen i teksten, men tolker selvstændigt på teksten og dermed går i dialog med eller problematiserer teksten). Resultatet er en typologi, der kan være med til at tydeliggøre den multimodale affordans, der er forsøgt fremstillet i et skema i Figur 4. 
Figur 4. Udkast til en fænomenologisk forankret teori om multimodale koblinger.

\begin{tabular}{|c|c|c|c|}
\hline Type & Beskrivelse & Funktion & Eksempler \\
\hline Konkretisering & $\begin{array}{l}\text { Abstrakt } \rightarrow \text { konkret } \\
\text { Krop, genstand, } \\
\text { billede eller diagram } \\
\text { konkretiserer sprog } \\
\text { eller symbolske } \\
\text { skrifttegn }\end{array}$ & $\begin{array}{l}\text { Konkret } \\
\text { anskueliggørelse, } \\
\text { der gør det nemmere } \\
\text { for elever at forstå } \\
\text { og erindre abstrakte } \\
\text { forhold }\end{array}$ & $\begin{array}{l}\text { En statuesamling } \\
\text { eller billeder i en } \\
\text { læsebog anskueliggør } \\
\text { handlingen i en tekst }\end{array}$ \\
\hline Specificering & $\begin{array}{l}\text { Abstrakt = konkret } \\
\text { Diagram, sprog eller } \\
\text { symbolske skrifttegn } \\
\text { specificerer krop, } \\
\text { genstand eller billede }\end{array}$ & $\begin{array}{l}\text { Præciserende kobling, } \\
\text { der gør det lettere for } \\
\text { elever at forstå og } \\
\text { identificere, hvad det } \\
\text { er, der konkret opleves }\end{array}$ & $\begin{array}{l}\text { En billedtekst } \\
\text { beskriver et billede, et } \\
\text { diagram tydeliggør og } \\
\text { identificerer en stribe } \\
\text { af valgmuligheder i en } \\
\text { film }\end{array}$ \\
\hline Forklaring & $\begin{array}{l}\text { Abstrakt } \rightarrow \text { konkret } \\
\text { Diagram, sprog } \\
\text { eller symbolske } \\
\text { skrifttegn forklarer } \\
\text { krop, genstand eller } \\
\text { billede på en generel } \\
\text { måde ud fra teori om } \\
\text { rækkefølge, årsag/ } \\
\text { virkning, motiver og } \\
\text { andre faktorer }\end{array}$ & $\begin{array}{l}\text { Forklarende } \\
\text { udlægning, der sætter } \\
\text { elevers oplevelse og } \\
\text { forståelse ind i en } \\
\text { større sammenhæng }\end{array}$ & $\begin{array}{l}\text { En billedtekst } \\
\text { forklarer et billede, } \\
\text { en aktantmodel } \\
\text { tydeliggør og forklarer } \\
\text { interagerende kræfter } \\
\text { i en tekst }\end{array}$ \\
\hline Komplementering & $\begin{array}{l}\text { Abstrakt + konkret } \\
\text { Krop, genstand, } \\
\text { billede, diagram, sprog } \\
\text { og/eller symbolske } \\
\text { skrifttegn supplerer } \\
\text { hinanden med } \\
\text { betydninger, der } \\
\text { tilsammen danner et } \\
\text { samlet udtryk }\end{array}$ & $\begin{array}{l}\text { Supplerende } \\
\text { interaktion, der styrker } \\
\text { det samlede udtryk, } \\
\text { fordi de enkelte udtryk } \\
\text { ikke kan stå alene }\end{array}$ & $\begin{array}{l}\text { En billedstribe og } \\
\text { dialog i en tekst } \\
\text { supplerer hinanden } \\
\text { og gør det muligt at } \\
\text { forbinde krop og replik }\end{array}$ \\
\hline Overføring & $\begin{array}{l}\text { Abstrakt }><\text { konkret } \\
\text { Krop, genstand og } \\
\text { billede, diagram, sprog } \\
\text { og/eller symbolske } \\
\text { skrifttegn udvider } \\
\text { hinanden ved at } \\
\text { overføre betydninger } \\
\text { og skabe et nyt og } \\
\text { flertydigt udtryk }\end{array}$ & $\begin{array}{l}\text { Overførsel af } \\
\text { betydning, der skaber } \\
\text { ny betydning og nye } \\
\text { perspektiver, som } \\
\text { involverer eleverne }\end{array}$ & $\begin{array}{l}\text { En billedroman hvor } \\
\text { billederne forskyder } \\
\text { synsvinklen fra første } \\
\text { til tredje person } \\
\text { og fokuserer på } \\
\text { mærkværdige detaljer, } \\
\text { der skaber nye } \\
\text { betydninger }\end{array}$ \\
\hline Problematisering & $\begin{array}{l}\text { Abstrakt } \leftrightarrow \text { konkret } \\
\text { Krop, genstand og } \\
\text { billede, diagram og } \\
\text { sprog problematiserer } \\
\text { hinanden ved at } \\
\text { modstille betydninger } \\
\text { og skabe et } \\
\text { modsætningsfyldt } \\
\text { udtryk }\end{array}$ & $\begin{array}{l}\text { Modstilling af } \\
\text { betydning, der } \\
\text { tvinger eleverne til } \\
\text { at reflektere over } \\
\text { udtrykkene, og det, de } \\
\text { repræsenterer }\end{array}$ & $\begin{array}{l}\text { En film hvor } \\
\text { et romantisk } \\
\text { handlingsforløb } \\
\text { undermineres af en } \\
\text { ironisk voice over }\end{array}$ \\
\hline
\end{tabular}


Ligheder og forskelle i forhold til Barthes og van Leeuwen skal ikke forfølges her. Til gengæld vil jeg slutte af med at præcisere betydningen af det fænomenologiske grundlag - herunder, at de mulige koblinger ikke blot vedrører ord og billede, men alle seks repræsentationsformer, og at de bestemmes nærmere ud fra den kognitive progression.

Sker der en kobling fra abstrakt til konkret repræsentation, er der tale om en konkretisering. Det kan være et billede, der anskueliggør en tekst; et diagram, der visualiserer relationelle forhold i en tekst; eller en kropslig handling, der konkretiserer symbolsk notation, fx en balanceøvelse som billede på ligningsprincippet repræsenteret ved symboler omkring et lighedstegn.

Omvendt har koblingen fra konkret til abstrakt enten form som identifikation og specificering eller som forklaring og udlægning. Det kan være en billedtekst, der benævner elementer på billedet; symboler, der udpeger elementer i en model; et diagram, der præciserer flugtveje på et billede, eller en brødtekst, der forklarer teorien bag en model.

Endelig er der en tredje måde at koble på til højre i skemaet, hvor der ikke er en bevægelse fra abstrakt mod konkret eller omvendt, men derimod et komplementært, integrerende eller kontrasterende forhold. Særligt den komplementære form er anvendt i modeller i fagtekster og læremidler, fordi billede, sprog og diagram repræsenterer forskellige dele af den teori, modellen repræsenterer som helhed. Til sammenligning er integrerende og kontrasterende koblinger mere udbredt inden for æstetiske tekster, og det kan blandt andet forklares med, at de typisk ikke søger fagtekstens entydighed, men derimod en æstetisk flertydighed.

Eksempler på multimodalitet hentes ofte fra naturfag, men for en nærmere betragtning, finder man dem i alle fag. Også i fx sprogfag, hvor man fx både bruger skemaer, vipper og symboler for sætningsled som repræsentation af syntaks. Således kan man konkretisere sætningers for- og bagvægt med en vippe eller specificere sætningsled med symbolerne "X", "O" og " $\Delta$ ".

Forskellige former for repræsentation af syntaks som eksempel på multimodalitet påkalder sig ikke så ofte opmærksomhed, men i betragtning af den opmærksomhed digitaliseringen har skabt over for multimodal repræsentation, kan det være meget godt at huske sig selv på, at multimodalitet kan tolkes fænomenologisk som et mere basalt, kropsligt forankret fænomen. Af samme grund er det ikke blot et grundlæggende fænomen, 
men også et relevant didaktisk begreb til analyse af repræsentationsformer i undervisningen. Selv om jeg argumenterer for at graduere kategorien for multimodalitet, så alle tekster ikke er lige multimodale, har jeg vanskeligt ved at forestille mig en nok så monomodal tekst omsat til undervisning uden en eller anden form for multimodalitet, der gør indholdet anskueligt og nærværende.

\section{Konklusion}

Udgangspunktet for denne artikel var et ønske om at sætte et kritisk-konstruktivt fokus på det sprog om multimodalitet, der har udviklet sig de seneste 15-20 år, med henblik på at videreudvikle det med bidrag fra en fænomenologisk semiotik. Det kritiske fokus blev med andre ord etableret i kraft af et udefrakommende perspektiv, hvilket giver en vis fare for at blive misforstået, selvom intentionen er gensidig befrugtning af forskellige traditioner.

Forudsætningen herfor er en forestilling om, at den socialsemiotiske diskurs er ved at være så stærk og veletableret, at det er muligt at få gang i en grundlagsdiskussion. Ikke for at ændre fokus eller genstandsfelt, da vi kan takke den socialsemiotiske multimodalitetsteori for at udvide tekstforskningens domæne. Denne udvidelse er forhåbentligt irreversibel. Hensigten er derimod at sætte kritisk fokus på begreberne, så det ikke bare er dem, vi udvider, men som sagt selve genstandsfeltet, der bliver udvidet.

Min kritik af den socialsemiotiske begrebsbrug peger på, at der på én gang er inspiration at hente i fx et udvidet begreb om 'modalitet', men også at der samtidig er en øget risiko for forveksling af begreber, fejloversættelser og en udvidelse af begrebet multimodalitet, så det mister sin funktion som prædikat. Konklusionen på artiklens kritiske del blev derfor, at der er behov for et skarpere fokus på definerende træk ved begreber, en mere adækvat oversættelse og reception af terminologien i de skandinaviske lande samt en mere kritisk og eksplicit forholden sig til traditioner og teoretisk grundlag. Kritikken skal ikke forstås som blot en positionering, men som en kritisk ansats til at komme videre.

Den opbyggelige del af artiklen griber derfor tilbage til en fænomenologisk semiotik for at demonstrere potentialet $i$ at fundere teorien om multimodalitet i en kropsligt forankret epistemologi, så de socialsemiotiske begrebsbestemmelser får 
et kognitivt korrelat. Resultatet er en dobbelt bestemmelse af repræsentation og multimodalitet ud fra henholdsvis et fænomenologisk og socialsemiotisk perspektiv, der gør det muligt at skitsere et bud på et sprog om multimodalitet sammenfattet i de to matricer i henholdsvis Figur 2 og 4.

Den dobbelte bestemmelse er tydelig i den vertikale niveaudeling i Figur 2 mellem kognitivt funderede repræsentationsformer, kulturelt bestemte semiotiske modi og en flerhed af empiriske eksempler. På den ene side rummer matricen således en forholdsvis stabil systematik for repræsentationsformer med henvisning til Peirces tredelte tegnbegreb og Husserls tredelte begreb om bevidsthedsakter. På den anden side er der en åben og undersøgende tilgang til mere sansespecifikke semiotiske modi, der ikke alene er bestemt ud fra en fænomenologisk epistemologi, men i lige så høj grad ud fra de kulturelle betingelser for tegndannelse.

Det er denne systematik, der gør det muligt at skitsere en kognitiv progression (gengivet på det horisontale plan i Figur 2 fra venstre mod højre), fremhæve prototypiske kognitive funktioner og sammenfatte de multimodale kombinationer i Figur 4. I forhold hertil tjener den korte analyse af den interaktive, multimodale model i Figur 3 to formål. Dels giver den et første indtryk af matricernes analytiske potentiale. Dels eksemplificerer den, at multimodal affordans (forholdet mellem repræsentationsformer og semiotiske modi) er mere end summen af de enkelte deles modale affordans. Det kortfattede eksempel er ikke udfoldet nok til at fungere som egentligt argument, men sammen med matricernes systematik og eksempler er det mit håb at have demonstreret det frugtbare $i$ at pode den socialsemiotiske multimodalitetsteori med en fænomenologisk semiotik med henblik på at udvikle en didaktisk analyse af multimodalitet.

\section{Referencer}

Andersen, T. H., Boeriis, M., Maagerø, E. \& Tønnessen, E. S. (2015). Social Semiotics. Key Figures, New Directions. London \& New York: Routledge.

Bruner, J. S. (1966). Studies in cognitive growth: a collaboration at the Center for Cognitive Studies. New York: Wiley.

Bybee, J., Perkins, R. \& William, P. (2012). The evolution of grammar. Chicago: University of Chicago Press.

Graf, S. T., Hansen, T. I. \& Hansen J. J. (2012). Loremidler i didaktikken didaktikken i loeremidler. Aarhus: Forlaget Klim. 
Hansen, T. I. (2010). Den fænomenologiske tilgang. I: S. V. Knudsen \& B. Aamotsbakken (Red.), Teoretiske tilnoerminger til pedagogiske tekster (s. 52-71). Oslo: Høyskoleforlaget.

Hansen, T. I. (2010). Multimodalitet som analysekategori. Viden om loesning, (7), 6-11.

Hansen, T. I. \& Skovmand, K. (2011). Foelles mål og midler. Loeremidler og loereplaner i teori og praksis. Aarhus: Forlaget Klim.

Husserl, E. (2005). Phantasy, image consciousness and memory. New York: Springer. (Original udgivelsesår 1898-1925).

Husserl, E. (1995). Logische Untersuchungen. Tübingen: Max Niemeyer. (Original udgivelsesår 1900-1901).

Jewitt, C. Re-thinking Assessment: Multimodality, literacy and computermediated learning. Assessment in Education, 10(1), 83-102. DOI: 10.1080/09695940301698

Jewitt, C., Bezemer, J. \& O'Halloran, K. (2016). Introducing Multimodality. London \& New York: Routledge.

Johansen, J. D. \& Larsen, S. E. (1994). Tegn i brug. København: Amanda/ dansklærerforeningen.

Kress, G. R. (2003). Literacy in the new media age. London \& New York: Routledge.

Kress, G. R. (1996). Representational Ressources and the Production of Subjectivity: Questions for the Theoretical Development of Critical Discourse Analysis in a Multicultural Society. I: C. R. Caldas-Coulthard \& M. Coulthard (Red.), Texts and Practices: Readings in Critical Discourse Analysis (s. 15-31). London \& New York: Routledge.

Kress, G. R. \& Leeuwen, T. (1996). Reading images - the Grammar of Visual Design. London \& New York: Routledge.

Lakoff, G. \& Turner, M. (1989). More Than Cool Reason: A Field Guide to Poetic Metaphor. Chicago: University of Chicago Press.

Peirce, C. S. (1998). Collected Papers of Charles Sanders Peirce, Vol. IVIII. I: C. Hartshorne, P. Weiss, A, Burks. (Red.). London: Thoemmes Press. (Original udgivelsesår 1931-1958).

Van Leeuwen, T. (2005). Introducing social semiotics. London \& New York: Routledge.

Weinberg, J. (2010). Review of Multimodality: A social Semiotic Approach to Contemporary Communication. Kairos: A Journal of Rhetoric, Technology and Pedagogy, 15(1). Lokaliseret den 30. august 2018 på: http://kairos. technorhetoric.net/15.1/reviews/weinberg/index.html 


\section{Learning Tech - Tidsskrift for læremidler, didaktik og teknologi Udgives af Læremiddel.dk}

Learning Tech er et forskningstidsskrift, hvor alle artikler er forskerbedømt i form af dobbeltblindt peer review. Tidsskriftet bringer artikler, der rammer genstandsfeltet mellem læremidler, didaktik og teknologi, og hensigten er at spille en betydelig rolle som platform for den voksende skandinaviske læremiddelforskning.

\section{Redaktion}

Stig Toke Gissel, UCL Erhvervsakademi og Professionshøjskole (ansvarshavende redaktør)

Anne-Mette Nortvig, Professionshøjskolen Absalon

Bettina Buch, Professionshøjskolen Absalon

Hildegunn Juulsgaard Johannesen, University College Syd

Marie Falkesgaard Slot, UCL Erhvervsakademi og Professionshøjskole René Boyer Christiansen, Professionshøjskolen Absalon

Stefan Ting Graf, UCL Erhvervsakademi og Professionshøjskole Stine Reinholdt Hansen, UCL Erhvervsakademi og Professionshøjskole Thomas R.S. Albrechtsen, University College Syd

\section{Redaktionssekretær}

Trine Ellegaard, UCL Erhvervsakademi og Professionshøjskole

\section{Temaredaktion}

Stig Toke Gissel, UCL Erhvervsakademi og Professionshojskole Bettina Buch, Professionshojskolen Absalon

Stine Reinholdt Hansen, UCL Erhvervsakademi og Professionshojskole

\section{Design og grafisk tilrettelæggelse}

Trefold - grafisk design og kommunikation

\section{Tryk}

Narayana Press, Gylling

ISSN 2445-7981 (Tryk)

ISSN 2445-6810 (Online)

\section{Rettigheder}

(c) 2018 Læremiddel.dk og forfatterne

\section{Kontakt}

Læremiddel.dk, Niels Bohrs Allé 1, 5230 Odense M www.laeremiddel.dk 